Cronfa - Swansea University Open Access Repository

This is an author produced version of a paper published in :

CATENA

Cronfa URL for this paper:

http://cronfa.swan.ac.uk/Record/cronfa25034

\title{
Paper:
}

Jiménez-Pinilla, P., Doerr, S., Ahn, S., Lozano, E., Mataix-Solera, J., Jordán, A., Zavala, L. \& Arcenegui, V. (2016). Effects of relative humidity on the water repellency of fire-affected soils. CATENA, 138, 68-76.

http://dx.doi.org/10.1016/j.catena.2015.11.012

This article is brought to you by Swansea University. Any person downloading material is agreeing to abide by the terms of the repository licence. Authors are personally responsible for adhering to publisher restrictions or conditions. When uploading content they are required to comply with their publisher agreement and the SHERPA RoMEO database to judge whether or not it is copyright safe to add this version of the paper to this repository. http://www.swansea.ac.uk/iss/researchsupport/cronfa-support/ 
Accepted manuscript version of: Jiménez-Pinilla, P., Doerr, S.H., Ahn, S., Lozanoa, E., MataixSolera, J., Jordán, A., Zavala, L.M. \& Arcenegui, V. (2016) Effects of relative humidity on the water repellency of fire-affected soils. Catena 138, 68-76. (doi:10.1016/j.catena.2015.11.012)

\section{Effects of relative humidity on the water repellency of fire-affected soils}

P. Jiménez-Pinilla ${ }^{\mathrm{a}, \mathrm{b},}$, S.H. Doerr ${ }^{\mathrm{c}}$, S. Ahn ${ }^{\mathrm{c}}$, E. Lozano ${ }^{\mathrm{a}, \mathrm{b}}$, J. Mataix-Solera ${ }^{\mathrm{a}, \mathrm{b}}$, A. Jordán ${ }^{\mathrm{b}}$, L.M. Zavala ${ }^{\mathrm{b}}$, V.

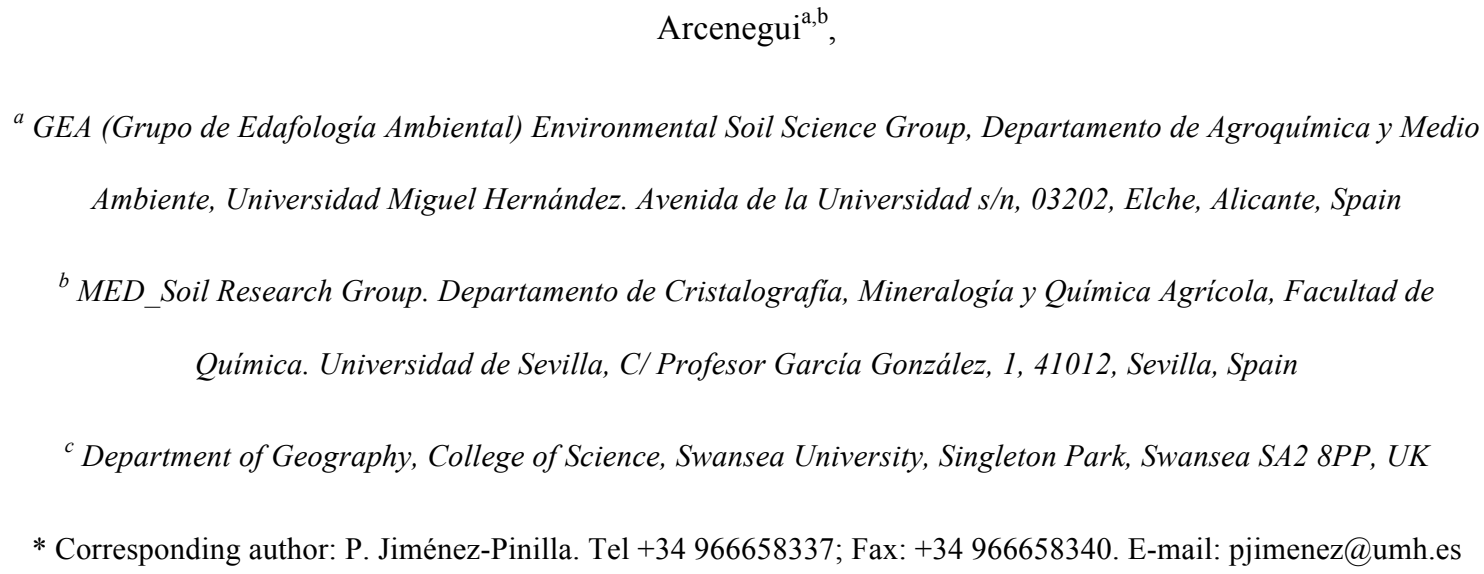

\section{Abstract}

Soil water repellency (SWR) is a common feature in unburned and particularly in fire-affected soils, and can enhance several environmental risks. It can be affected by many factors such as vegetation cover, moisture content and, in fire-affected areas, the degree of heating during burning. In addition, experiments using unburned soils have shown that atmospheric relative humidity can affect their water repellency. The purpose of this laboratory study was to examine how ambient relative humidity (RH) affects SWR of burned soils, and to explore its implications for fire-affected regions. Soil samples were taken from under fire-prone, but long unburned Pinus halepensis and a shrub site in Gorga, Alicante (SE Spain). In order to simulate different fire severities, samples were heated for 20 minutes at different temperatures $(50,100$, $150,200,250,300$ and $\left.350^{\circ} \mathrm{C}\right)$. Samples were then equilibrated at different RHs (30, 50, 70 and $95 \%)$ in a sealed climate chamber at a constant temperature of $20^{\circ} \mathrm{C}$. The water drop penetration time (WDPT) test, molarity of ethanol droplet (MED) test, and advancing contact angle (CA) measurements were performed inside the sealed climate chamber to assess SWR for each sample and treatment. Overall, increasing heat treatments enhanced SWR, which in turn was enhanced further following exposure to high RHs. The WDPT test showed that soils under pine 
Accepted manuscript version of: Jiménez-Pinilla, P., Doerr, S.H., Ahn, S., Lozanoa, E., MataixSolera, J., Jordán, A., Zavala, L.M. \& Arcenegui, V. (2016) Effects of relative humidity on the water repellency of fire-affected soils. Catena 138, 68-76. (doi:10.1016/j.catena.2015.11.012)

were water repellent at the lowest heating temperature and became strongly water repellent at the higher heating temperatures and near saturation $(95 \% \mathrm{RH})$. Shrubland soils were mostly wettable at the onset and remained so at every RH level studied except being slightly SWR at 95\% RH. A similar trend was found after MED and CA measurements. The results demonstrate that high RH contributes to enhanced SWR also in burned soils, where high temperatures had already led to a substantial enhancement of SWR. These findings suggest that SWR levels determined for fire affected areas ambient under field or laboratory conditions may underestimate the apparent SWR levels present at the high RH levels that often precede major storm events. This in turn has implications for predicting post-fire runoff and erosion events.

Key words: Hydrophobicity; Relative humidity; Contact angle; Pre-heated temperatures; Forest soils; Mediterranean calcareous soils;

\section{Introduction}

Soil water repellency (SWR) may be defined as the condition of a soil which does not wet spontaneously when water comes in contact with the soil surface (Leelamanie et al., 2008a). This behaviour modifies infiltration and evaporation rates, erodibility and other hydrological processes of soils (Feng et al., 2001; Jordán et al., 2009; Wallis et al., 1991; Wallis and Horne, 1992). SWR is a common property of soils under many vegetation types and is often induced in previously wettable soils or enhanced by fire (DeBano, 2000; Doerr et al., 2000; Granged et al., 2011 a; Jordán et al., 2013; Jordán et al., 2014). It has been shown that environmental conditions such as ambient temperature (King, 1981; Goebel et al., 2011), drying temperature (Franco et al., 1995; Dekker et al., 1998), water content (Berglund and Persson, 1996; Bodí et al., 2013; DeJonge et al., 1999; Dekker and Ritsema, 2000) and the wetting and drying history of samples (Doerr and Thomas, 2000) can strongly affect SWR. Atmospheric relative humidity (RH) is 
Accepted manuscript version of: Jiménez-Pinilla, P., Doerr, S.H., Ahn, S., Lozanoa, E., MataixSolera, J., Jordán, A., Zavala, L.M. \& Arcenegui, V. (2016) Effects of relative humidity on the water repellency of fire-affected soils. Catena 138, 68-76. (doi:10.1016/j.catena.2015.11.012)

another important factor conditioning SWR. Jex et al. (1985) and Doerr et al. (2002) reported that SWR increased when soil was exposed to $>90 \% \mathrm{RH}$ (near saturation) over a short period ( $<1$ day), but gradually decreased when exposed to an ambient laboratory atmosphere of $\sim 40 \%$ RH. Leelamanie et al. (2008b) reported a positive correlation between RH and SWR at RHs between 33 and 94\%. Another main factor that recently has been considered responsible of the severity of SWR is the soil surface structure (Ahn, 2014). SWR appears on low-energy surfaces where the attraction between the molecules of the solid and liquid interface is weak (Heslot et al., 1990; Roy and McHill, 2002). Under natural conditions, high-energy soil mineral surfaces are often covered by films of low-energy organic compounds (Doerr et al., 2000; Goebel et al., 2004) forming water repellent surfaces (Jiménez-Morillo et al., 2014; Leelamanie et al., 2008a) and this can be amplified by surface structure (Wenzel, 1936; Cassie and Baxter, 1944). It has been reported that the overall susceptibility to developing soil water repellency is higher in sandy and coarser textures (González-Peñaloza et al., 2013; McGuie and Posner, 1980; Roberts and Carbon, 1971) and lower in those containing clay (Crockford et al., 1991; Zavala et al., 2014). A soil surface may minimize the contact area with a water drop by its porous structure. In soils prone to develop water repellency, the upper soil layers tend to exhibit the greatest severity. This effect is usually enhanced as soil dries and water is lost from the pores, enlarging the air-solid interface, which critically increases the net contact angle (Ahn, 2014). The contact angle (CA) between the solid and water can be measured at the three-phase interface (gasliquid-solid). According to Goebel et al. (2011) SWR occurs if CA $>0^{\circ}$; soils show reduced wettability with CA varying between 0 and $90^{\circ}$ (i.e. infiltration of water into the soil matrix decreases); and values of $\mathrm{CA}>90^{\circ}$ indicate extreme SWR. A zero CA occurs when the surface tension of solid and liquid are equal to each other (Bachmann and van der Ploeg, 2002). Although, numerous studies have used CA to determine SWR (Carrillo et al., 1999; Bachmann et al., 2000a, b; Leelamanie et al., 2008b; Doerr et al., 2009), and some studies exist in which 
Accepted manuscript version of: Jiménez-Pinilla, P., Doerr, S.H., Ahn, S., Lozanoa, E., MataixSolera, J., Jordán, A., Zavala, L.M. \& Arcenegui, V. (2016) Effects of relative humidity on the water repellency of fire-affected soils. Catena 138, 68-76. (doi:10.1016/j.catena.2015.11.012)

the effect of RH on SWR has been examined (Jex et al., 1985; Doerr et al., 2002; Leelamanie et al., 2008b). All previous studies have been carried out on unburned soils.

Fire is an important ecological agent, which has increasingly affected Mediterranean ecosystems in the last decades, leading to changes in chemical, physical and microbiological soil properties (Neary et al., 1999; Certini, 2005). Fire may induce or increase SWR in previously wettable or water-repellent soils (Doerr et al., 2000; Mataix-Solera and Doerr, 2004; Zavala et al., 2009a), but can also destroy it after intense combustion of organic matter (Arcenegui et al., 2008; Granged et al., 2011b; Jordán et al., 2010; Robichaud and Hungerford, 2000). The specific effect depends mostly on the duration of heating and temperatures reached (DeBano, et al., 1976; Doerr et al., 2004; Gordillo-Rivero et al., 2014), but also oxygen availability (Bryant et al., 2005) and soil water content (Robichaud and Hungerford, 2000; Zavala et al., 2010).

The influence of increasing temperatures and RH on SWR is of substantial importance in affecting ecosystem processes, which regulate the soil system during post-fire recovery. Given the fact that fire-affected soils often exhibit particularly high levels of SWR, the removal of the protective vegetation cover during fire can make such soils particularly susceptible to accelerated hydrological and geomorphological responses (Doerr et al., 2009). An important research gap thus exists in elucidating the effects of RH on SWR of soils that have been exposed to heating during vegetation fires.

The main aim of this study was therefore to explore the effect of different ambient RHs on SWR variations that might prevail under very dry surface conditions following a wildfire. We focused here on a Mediterranean calcareous soil under Pinus halepensis and mixed shrub vegetation, which is a common soil-vegetation combination subjected to fire in Eastern Spain (MataixSolera et al., 2002; Arcenegui et al., 2008; Mataix-Solera et al., 2013; Jiménez-Pinilla et al., 2015). 
Accepted manuscript version of: Jiménez-Pinilla, P., Doerr, S.H., Ahn, S., Lozanoa, E., MataixSolera, J., Jordán, A., Zavala, L.M. \& Arcenegui, V. (2016) Effects of relative humidity on the water repellency of fire-affected soils. Catena 138, 68-76. (doi:10.1016/j.catena.2015.11.012)

\section{Material and methods}

103

104

105

106

107

108

109

110

111

112

113

114

115

116

117

118

119

120

121

122

123

124

125

126

\subsection{Sampling site, soil sampling and experimental design}

The sampling site is located in a formerly cultivated area in Gorga ( $\mathrm{N} 38^{\circ} 43^{\prime} 44^{\prime \prime}$, W $0^{\circ}$ $22^{\prime} 58^{\prime \prime}$; 545 masl), province of Alicante (SE Spain), with a Mediterranean climate type and approximate annual average rainfall of $500 \mathrm{~mm}$. Vegetation type is mainly composed of $P$. halepensis forest and an understory stratum formed by Mediterranean shrubs, including Quercus coccifera, Rosmarinus officinalis, Cistus albidus and Erica arborea. The soil is classified as a Lithic Xerorthent (Soil Survey Staff, 2014), developed over limestone with a silt loam texture (49.7\% sand, $40.7 \%$ silt and $9.6 \%$ clay). Surface soil samples $(0-2.5 \mathrm{~cm}$ depth) were collected beneath either well-demarcated pine or shrub areas after carefully removing any superficial litter by hand. Samples were stored in plastic bags, transported to the laboratory, air dried at room temperature $\left(\sim 25^{\circ} \mathrm{C}\right)$ for one week and then carefully sieved through a $<2$-mm mesh.

Soil samples were homogenized before the heating procedure. Then triplicate soil samples $(\sim 30$ g) were heated at selected temperatures under controlled laboratory conditions $(50,100,150$, 200, 250, 300 and $350{ }^{\circ} \mathrm{C}$ ), during 20 minutes in ceramic crucibles using a muffle furnace (Nabertherm, P320, Bremen, Germany). This range of temperatures was selected in order to simulate different potential heating scenarios of wildfires and also in agreement with previous studies which have shown notable heat-induced increases in SWR (Neary et al., 1999; Bachmann et al., 2003; Doerr et al., 2005a; Mataix-Solera et al., 2011). For each case, the furnace was pre-heated to the desired temperature and each sample was heated separately. The experiment includes also unheated control samples.

\subsection{Exposure to selected relative humidities and associated water repellency measurements} using WDPT and MED tests 
Accepted manuscript version of: Jiménez-Pinilla, P., Doerr, S.H., Ahn, S., Lozanoa, E., MataixSolera, J., Jordán, A., Zavala, L.M. \& Arcenegui, V. (2016) Effects of relative humidity on the water repellency of fire-affected soils. Catena 138, 68-76. (doi:10.1016/j.catena.2015.11.012)

127 For each experiment, each heated soil sample was divided into 3 subsamples (10 g, 128 approximately), which were then put in petri dishes (5-mm diameter and 7-mm depth), and 129 placed inside a climate chamber (SANYO Gallenkamp, model PLC CF4; range: 30-90\% RH 130 and -40 to $180{ }^{\circ} \mathrm{C}$ temperature) and subsequently exposed for equilibrium under a different 131 prescribed atmospheric conditions of $30,50,70$ and $95 \% \mathrm{RH}$ at $20{ }^{\circ} \mathrm{C}$. Each sample type, in 132 triplicate, was kept for 48 hours inside the chamber prior to the water repellency assessments, to 133 ensure the entire sample was fully adjusted to the selected humidity. Soil samples remained 134 within the sealed climate chamber throughout the experiments, with manipulations and 135 measurements conducted by using gloves attached to sealed portholes in the chamber window. 136 This ensured that samples remained under constant environmental conditions and without any other environmental variables affecting them.

138 Persistence of SWR was assessed using the water drop penetration time (WDPT) test, which 139 measures how long SWR persists on a porous surface. Given that SWR usually decays with 140 prolonged water contact, it relates to the hydrological implications of reduced wettability as the 141 amount of surface runoff is affected by the time required for the infiltration of raindrops 142 (Wessel, 1988; Doerr, 1998). It involved placing three drops of distilled water $(\sim 0.02 \pm 0.05 \mathrm{~mL})$ 143 onto the soil sample surface. In each case, the time (in seconds) required for a complete droplet 144 infiltration was recorded and a SWR persistence class assigned according to Bisdom et al. 145 (1993) (Table 1).

146 Severity of SWR was also assessed inside the chamber using the molarity of an ethanol droplet 147 (MED) test (expressed as \% ethanol; Doerr et al., 1998) (Table 2). This test is an indirect 148 measure of the surface tension of the soil surface and indicates how strongly a water drop is 149 repelled by a soil at the time of application (King, 1981; Doerr, 1998). It involved placing 3 150 droplets $(\sim 0.02 \pm 0.05 \mathrm{~mL})$ using an applicator of water-ethanol solution $(0,1,3,5,8.5,13,18$, $15124,36 \%$ ethanol) (Table 2) onto the soil samples surfaces. The number of droplets that 152 penetrate the soil within 5 seconds (Crockford et al., 1991) was recorded for each ethanol 
Accepted manuscript version of: Jiménez-Pinilla, P., Doerr, S.H., Ahn, S., Lozanoa, E., MataixSolera, J., Jordán, A., Zavala, L.M. \& Arcenegui, V. (2016) Effects of relative humidity on the water repellency of fire-affected soils. Catena 138, 68-76. (doi:10.1016/j.catena.2015.11.012)

153

solution and the solution that allowed more than one drop to penetrate was then taken to assign a SWR severity class (Doerr, 1998) (Table 2).

\subsection{Additional water repellency assessments using advancing contact angle measurements}

The advancing contact angle (CA) of a water droplet on a soil can also be used to determine the severity of SWR (Letey, 2000; Leelamanie, 2008a). In surface science, a CA of $90^{\circ}$ is usually taken as demarcating water repellent and wettable conditions on flat media (Letey, 2000). For porous granular media such as soils, it has been suggested that reduced wettability is present for $0^{\circ}<\mathrm{CA}<90^{\circ}$; and values of CA $>90^{\circ}$ indicate extreme SWR (Goebel et al., 2011; Fig. 1). More specifically, Shirtcliffe et al. (2006) found that the critical contact angle for penetration was $52-61^{\circ}$ using soil models and test liquids (pentane and hexane), but years before Bán et al. (1987) had determined CA even lower (49.5-57.7) using ethanol and sulphur pellets, polyamide and polytetrafluoroethylene. CA measurements were included in this study as third measure of SWR (i) to provide wider comparability of the SWR data obtained here and (ii) as CA measurements have not been included in any previous study in which the effect of RH on SWR had been examined.

To measure the CA of a sample, a monolayer of soil particles was immobilized on a microscope glass slide $(1.5 \mathrm{~cm} \times 3 \mathrm{~cm})$ using double-sided adhesive tape to accomplish a plain homogeneous surface (Bachmann et al., 2000b). Samples were then placed on a tray inside the sealed climate chamber and exposed to the selected RH's as in the previous experiments, except that samples were only exposed for 24 hours given that only a monolayer of soil was used.

We also included two different hydrophobic control 'model soil' materials in this experiment: spherical glass beads to represent smooth-spherical particles (obtained from Whitehouse Scientific, UK); and natural quartz sand (collected from fluvial deposits, South Wales, UK) to represent textured-angular particles typical of soils. Both materials were used in two different 
Accepted manuscript version of: Jiménez-Pinilla, P., Doerr, S.H., Ahn, S., Lozanoa, E., MataixSolera, J., Jordán, A., Zavala, L.M. \& Arcenegui, V. (2016) Effects of relative humidity on the water repellency of fire-affected soils. Catena 138, 68-76. (doi:10.1016/j.catena.2015.11.012)

178 size ranges: $710-850 \mu \mathrm{m}$ and $1120-1180 \mu \mathrm{m}$ and were chemically hydrophobized using 179 chlorotrimethylsilane as described in Ahn et al. (2013), resulting in static (temporally stable) 180 water repellency. They were then packed as closely as possible and immobilized on the glass 181 slides as described above.

182 It is now well established that hydrophobicity can be enhanced by the micro-topography of a 183 surface when compared to flat surfaces (McHale et al., 2005). For particle arrays as presented 184 by a soil surface, the texture of the particle surface itself seems to have a significantly greater 185 influence in the amplification of the CA (i.e. and hence SWR) than the coarser-scale particle186 based structure or particle shape (Bachmann et al., 2006; Ahn, 2014). Hence these 'model soil' 187 materials, varying in surface texture (glass beads: spheres with no particle surface texture and sand: textured-angular particles), were included to explore the fundamental physical impact of

189 RH and surface texture on SWR behaviour for a static (i.e. chemically more stable) hydrophobic 190 coating that is expected not to be altered by microbial activities. .

191 For CA assessment, drops of distilled water were placed onto the surfaces of soils and 192 chemically treated materials using a 1-mL syringe with a blunt tip needle (19 gauge Luer-Lock 193 blunt ended needles, Sylmaste, UK). The advancing contact angles of sessile drops were recorded by a video camera (30 fps) while the water drop was being gradually enlarged ( 10 -

$195100 \mu \mathrm{L}$ ). The left and right hand side contact angles of each advancing moment were 196 determined using the software ImageJ (Version 1.48, National Institutes of Health, USA) and 197 averaged, and then 3-5 advancing CAs were averaged from each sample in triplicate. All 198 samples remained in the sealed climate chamber throughout the experiments, as described 199 above.

\subsection{Statistical analysis}

202 The normal distribution of SWR data was checked using the Kolmogorov-Smirnov test. As 
Accepted manuscript version of: Jiménez-Pinilla, P., Doerr, S.H., Ahn, S., Lozanoa, E., MataixSolera, J., Jordán, A., Zavala, L.M. \& Arcenegui, V. (2016) Effects of relative humidity on the water repellency of fire-affected soils. Catena 138, 68-76. (doi:10.1016/j.catena.2015.11.012)

normality of SWR data was rejected $(\mathrm{p}<0.05)$, WDPT data were transformed $(\mathrm{Ln})$ to allow a better data display given their large variability. Mann-Whitney $U$ test was used to check the statistical differences between SWR data at each temperature treatment regarding to unheated (control) samples for every RH studied $(\mathrm{p}<0.05)$. Statistical analyses were performed by IBM $^{\circledR}$ SPSS (@ SPSS Inc., 1989) version 22 for Windows software package.

\section{Results}

\subsection{Heating effects on soil water repellency at a standard humidity (50\% RH)}

Heating has a similar effect for both persistence (WDPT test) and severity (MED and CA tests) of water repellency for samples at a standard laboratory RH of 50\%. For the WDPT test, an apparent slight increase in SWR for pine soils was observed at $50{ }^{\circ} \mathrm{C}$ compared to the control samples (unheated), and also an apparent decrease between 100 and $200{ }^{\circ} \mathrm{C}$, although in both cases, no significant differences were observed $(\mathrm{p}>0.05)$ (Fig. 2a). For the highest heating temperatures $\left(300-350{ }^{\circ} \mathrm{C}\right)$, a substantial increase in SWR was observed, with significant differences $(p<0.05)$, with the peak occurring at $350{ }^{\circ} \mathrm{C}$ (Fig. 2a). SWR was not found at $50 \%$ RH in shrub soils for any heating treatment (Fig. 2b).

The MED tests showed a similar pattern with WDPT tests for both pine and shrub soils (Fig. 3a and $3 b$, respectively). Nevertheless, significant differences $(p<0.05)$ were found on SWR pine samples from $250{ }^{\circ} \mathrm{C}$ to $350{ }^{\circ} \mathrm{C}$ campared to the unheated samples. SWR was not detected by MED tests in pine soils heated at 150 and $200{ }^{\circ} \mathrm{C}$ (Fig. 3a).

The results of CA measurements showed a similar pattern with the WDPT results. CA measurements at $50 \% \mathrm{RH}$ showed a general trend of increasing SWR with heating temperatures showing the largest $\mathrm{CA}$ at the highest heating range, where significant differences were found from 200 to $350{ }^{\circ} \mathrm{C}$ with regarding to unheated (control) samples $(\mathrm{p}<0.05)$ (Fig. 4). 
Accepted manuscript version of: Jiménez-Pinilla, P., Doerr, S.H., Ahn, S., Lozanoa, E., MataixSolera, J., Jordán, A., Zavala, L.M. \& Arcenegui, V. (2016) Effects of relative humidity on the water repellency of fire-affected soils. Catena 138, 68-76. (doi:10.1016/j.catena.2015.11.012)

\subsection{Relative humidity effects on soil water repellency persistence (WDPT test)}

229 Persistence of SWR in pine soils increased with RH for all heating temperatures. The WDPTs were longest at the highest RH (95\%) for the most of heating treatments (Fig. 2). Particularly, for the heating treatments at $300{ }^{\circ} \mathrm{C}$, the $\ln$ WDPT increased from $5.1 \mathrm{~s}$ at $50 \% \mathrm{RH}$ to $8.6 \mathrm{~s}$ at $95 \%$ $\mathrm{RH}$, and for the treatment at $350{ }^{\circ} \mathrm{C}$, the ln WDPT increased from $5.1 \mathrm{~s}$ at $50 \% \mathrm{RH}$ to $8.4 \mathrm{~s}$ at $95 \%$ RH (Fig. 2a), being in both cases significantly different $(p<0.05)$. For these samples for the $300{ }^{\circ} \mathrm{C}$ and $350{ }^{\circ} \mathrm{C}$ treatments were 'severely water repellent' (ln WDPT 6.4-6.8 s in Table 1) at

Shrub soils were wettable at the onset $(\ln$ WDPT $<1.6 \mathrm{~s})$ and remained stable at each considered $\mathrm{RH}$ except at $95 \% \mathrm{RH}$, where the samples heated at $250{ }^{\circ} \mathrm{C}$ and $300{ }^{\circ} \mathrm{C}$ were 'slightly water repellent' (ln WDPT 1.8-3.4 s in Table 1; Fig. 2b), and there were statistically significant differences $(\mathrm{p}<0.05)$.

\subsection{Relative humidity effects on soil water repellency severity (MED and CA tests)}

243 For the MED test, an influence of RH on SWR was observed mainly for the pine soils, showing

244 a consistently increasing severity of water repellency with increasing RH (Fig. 3). At 30 and $24570 \% \mathrm{RH}$, severity of SWR ranged between very wettable and strongly water repellent (classes 1 to 6; Table 2), with the highest values occurring for the highest temperature treatments (Fig. 3a),

247 and where also statistically significant differences were detected for both RHs at $250{ }^{\circ} \mathrm{C}$ and 300

$248{ }^{\circ} \mathrm{C}(\mathrm{p}<0.05)$. At 95\% RH (Fig. 3a), SWR ranged between moderately and extremely water repellency (classes 5 to 9 ; Table 2), and the increase of SWR detected at $300{ }^{\circ} \mathrm{C}$ was statistically

250 significant different $(\mathrm{p}<0.05)$.

251 In contrast, the influence of RH on SWR was not shown from the shrub soils at low RH levels, 252 as the shrub soils were wettable at the onset (ethanol $<0 \%$ ), and remained so at every RH level 
Accepted manuscript version of: Jiménez-Pinilla, P., Doerr, S.H., Ahn, S., Lozanoa, E., MataixSolera, J., Jordán, A., Zavala, L.M. \& Arcenegui, V. (2016) Effects of relative humidity on the water repellency of fire-affected soils. Catena 138, 68-76. (doi:10.1016/j.catena.2015.11.012)

monitored except at $95 \% \mathrm{RH}$. Even at $95 \% \mathrm{RH}$, only the samples heated at 250,300 and $350{ }^{\circ} \mathrm{C}$

(Fig. 3b) were 'slightly water repellent' (class 4; Table 2), and with no significant differences (p $>0.05)$.

The CA measurements were only conducted on samples taken from the pine site as only these showed a resistance to wetting sufficient for conducting CA measurement $\left(\mathrm{LN}_{\mathrm{WDPT}}>1.6 \mathrm{~s}\right)$.

258 Shrub soils had rapid infiltration of water droplet, and thus, CAs were not technically measurable.

260

The CA measurements for the pine soils also showed an effect of RH at all heating temperatures at 30 and $70 \%$ RH (Fig. 4). The most noticeable increase in CA was found in the samples heated between 250 and $350{ }^{\circ} \mathrm{C}$, particularly for 30 and $70 \%$ RH (Fig. 4), where significant differences were also detected $(\mathrm{p}<0.05)$. The highest $\mathrm{CA}$ was observed at $95 \% \mathrm{RH}$ after all heating treatments (Fig.4), finding significant differences $(\mathrm{p}<0.05)$ from $200{ }^{\circ} \mathrm{C}$ forward.

\subsection{Relative humidity effects on 'model soils': glass beads and sand}

Both glass beads and sand showed a similar pattern where CA increased with RH (Fig. 5). CAs observed on glass beads of different sizes ranged from $77.91^{\circ}\left(66.5^{\circ}, 85.6^{\circ}\right)$ to $100.9^{\circ}\left(88.5^{\circ}\right.$, $\left.107.9^{\circ}\right)$ (Fig. 5a), and on sands from $117.7^{\circ}\left(100.0^{\circ}, 126.0^{\circ}\right)$ to $125.9^{\circ}\left(118.3^{\circ}, 128.9^{\circ}\right)($ Fig. $5 b)$.

The CAs of glass beads at different relative humidities all indicated water repellency (according to the classification of Goebel et al., 2011). The CA of the glass beads of size $1120-1180 \mu \mathrm{m}$ at $95 \% \mathrm{RH}$ was $100.9^{\circ}\left(88.5^{\circ}, 107.9^{\circ}\right)$, indicating a fully water repellent behaviour $\left(\mathrm{CA}>90^{\circ}\right)$ (Fig. 5a). The sand of both size groups also had consistent water repellent behavior $\left(\mathrm{CA}>90^{\circ}\right)$.

274 The CA was $123.2^{\circ}\left(111.3^{\circ}, 127.1^{\circ}\right)$ for size $710-850 \mu \mathrm{m}$ and $125.9^{\circ}\left(118.3^{\circ}, 128.9^{\circ}\right)$ for size 275 1120-1180 $\mu \mathrm{m}$ (Fig. 5b). Regarding the differences between two sizes of sands, we observed 276 that CAs were slightly larger for the smaller particles $(710-850 \mu \mathrm{m})$ compared to the larger ones $277(1120-1180 \mu \mathrm{m})$ at 30,50 and $70 \% \mathrm{RH}$, and the opposite at 95\% RH (Fig. 5b). 
Accepted manuscript version of: Jiménez-Pinilla, P., Doerr, S.H., Ahn, S., Lozanoa, E., MataixSolera, J., Jordán, A., Zavala, L.M. \& Arcenegui, V. (2016) Effects of relative humidity on the water repellency of fire-affected soils. Catena 138, 68-76. (doi:10.1016/j.catena.2015.11.012)

\section{Discussion}

4.1 Heating effects on soil water repellency at different pre-established laboratory relative humidities

282 An overall increasing trend of both persistence (determined using the WDPT test) and severity 283 (MED and CA tests) of SWR with increasing heating temperature was detected from pine soils at a standard RH of 50\%. More specifically, SWR increased somewhat at the lowest heating temperature $\left(50^{\circ} \mathrm{C}\right)$ compared to unheated samples (Fig. 2a, 3a, 4). The SWR increasing can be caused by increased alignment of hydrophobic molecule chains (Doerr et al., 2005b). This was followed by a slight reduction for 100 and $150{ }^{\circ} \mathrm{C}$ treatments. The reason for this is unclear. Following heating at $200-300{ }^{\circ} \mathrm{C}$ a strong increase in SWR was observed (Fig. 2a, 3a, 4) which is in agreement with established knowledge based on previous laboratory studies, which have shown intesification of SWR when soil temperatures reach $175-270{ }^{\circ} \mathrm{C}$ (Doerr and Shakesby, 2009). Amongst the suggested causes for strong increases in SWR by heating are migration of hydrophobic material from interstitial organic matter onto soil particles (Franco et al., 1994) and chemical changes such as the relative increase in long chain $(<\mathrm{C} 20)$ fatty acids aromatic compounds (Atanassova and Doerr, 2011). Krammes and DeBano (1965) found that SWR is

295 destroyed at temperatures between 280 and $400{ }^{\circ} \mathrm{C}$, with the specific destruction temperature being closer to $280{ }^{\circ} \mathrm{C}$ for shorter heating durations (Doerr et al., 2004). In the current study, however, heat treatments at $350{ }^{\circ} \mathrm{C}$ seem to be remained below the threshold for SWR destruction.

Shrub soils remained wettable after all heating treatments, highlighting the importance of vegetation type on the development of water repellency. It has been previously reported in

301 burned (Arcenegui et al., 2007; Mataix-Solera et al., 2008) or unburned soils (Jordán et al., 2008; Martínez-Zavala and Jordán-López, 2009; Zavala et al., 2014). 
Accepted manuscript version of: Jiménez-Pinilla, P., Doerr, S.H., Ahn, S., Lozanoa, E., MataixSolera, J., Jordán, A., Zavala, L.M. \& Arcenegui, V. (2016) Effects of relative humidity on the water repellency of fire-affected soils. Catena 138, 68-76. (doi:10.1016/j.catena.2015.11.012)

\subsection{Relative humidity effects on the persistence and severity of soil water repellency}

305

306

307

Persistence and severity of SWR were substantially enhanced at the highest RH applied in our experiments. At $95 \% \mathrm{RH}, \mathrm{SWR}$ in pine soils exhibited the highest values for each heating temperature (Fig. 2a, 3a, 4), and the shrub soils that were wettable at all other RHs turned into slightly water repellent at 95\% (Fig. 2b, 3b).

A notable increase in SWR also occurred for pine soils at $70 \% \mathrm{RH}$ compared to the standard atmosphere of $50 \% \mathrm{RH}$, particularly when considering SWR severity measured by MED test. This was evident in all samples irrespective of heating temperatures (Fig. 3a). These results demonstrate a considerable enhancing influence of high RHs (near atmosphere saturation: 95\% RH) on SWR persistence and severity of already water-repellent soil. This fact suggests that air humidity is a key control of SWR. It supports findings from previous work on a variety of unburned soils (Jex et al., 1985; Doerr et al., 2002; Leelamanie and Karube, 2007; Leelamanie et al., 2008b), and demonstrates that this also applies to heat-affected soils. Given the relatively rapid change observed also in previous laboratory tests, Doerr et al. (2002) proposed that physicochemical rather than microbiological processes may be responsible for this soil behaviour. They suggested that the prior interactions between soil components and water vapour at high RH may be of significant influence, as a considerable quantity of energy is released, which might be disrupting the mineral and organic hydrophobic bonds within the soil. They speculated that, similar to heating effects, the condensation and adsorption of water vapor onto soil associated with an increase in RH might lead to reorientation of the hydrophobic organic molecule chains, expanding more strongly into pore spaces, thereby enhancing SWR.

In this study, the heated samples, in which SWR had already been increased through the effect of temperature, showed further enhanced SWR by high RHs. Considering that high temperature treatments up to $300{ }^{\circ} \mathrm{C}$ would have led to a substantial reduction in any viable soil microbial 
Accepted manuscript version of: Jiménez-Pinilla, P., Doerr, S.H., Ahn, S., Lozanoa, E., MataixSolera, J., Jordán, A., Zavala, L.M. \& Arcenegui, V. (2016) Effects of relative humidity on the water repellency of fire-affected soils. Catena 138, 68-76. (doi:10.1016/j.catena.2015.11.012)

population (Guerrero et al., 2005; Mataix-Solera et al., 2009), thereby limiting the growth of both bacteria (Díaz-Raviña et al., 1996) and also fungi (Widden and Parkinson, 1975), the intensified SWR by RH does not seem to be driven by increased microbial activity within a relatively short-duration of exposure to high humidities (Doerr et al,. 2002).

It is also noteworthy that a slight increase in SWR was observed for pine soils at $30 \% \mathrm{RH}$, compared to the standard atmosphere of $50 \% \mathrm{RH}$. This was less consistent across the heattreated soils and was evident predominantly from WDPT and MED tests (Fig. 2a, 3a), and also "hyper-dry" conditions is much slower (days to weeks) than the time scale of rainstorms (minute to hours). RHs of $30 \%$ can be considered a threshold for hot dry summer weather conditions in the Mediterranean climate (Harpaz et al., 2014), and this behaviour may therefore be relevant to the study region.

\subsection{Assessments of relative humidity effects on 'model soils': glass beads and sand}

343 The observed increase in SWR severity of hydrophobic 'model soil' samples after a short

344 exposure (24 h) to relatively high RHs (> 50\%) (Fig. 5a, b) suggests that the enhanced water

345 repellency with RH observed here is a generic effect by a physical mechanism. The 'model soils' 346 were hydrophobized with a chemically relatively stable compound, and thus there is lowest

347 possibility for microbial activities to get involved for these materials.

348 It supports the conclusion already stated above that physical rather than microbial processes are responsible for enhanced SWR at high $\mathrm{RH}$. 
Accepted manuscript version of: Jiménez-Pinilla, P., Doerr, S.H., Ahn, S., Lozanoa, E., MataixSolera, J., Jordán, A., Zavala, L.M. \& Arcenegui, V. (2016) Effects of relative humidity on the water repellency of fire-affected soils. Catena 138, 68-76. (doi:10.1016/j.catena.2015.11.012)

352 SWR is a widespread phenomenon with the capacity to condition hydrological and 353 geomorphological processes (Whelan et al., 2015). It can reduce infiltration rates (Wallach and 354 Graber, 2007) and water retention capacity (Naasz et al., 2005). Important environmental

355

356

357

358

359

360

361

362

363

364

365

366

367

368

369

370

371

372

373

374 To the authors' knowledge, this is the first study in which RH effects on SWR have been 375 376 consequences of the reduced infiltration rate include increased soil erosion, enhanced overland flow and non uniform wetting fronts with fingered flow (Burch et al., 1989; Imeson et al., 1992; Ritsema et al., 1993; Jordán et al., 2008; Zavala et al., 2009b). These environmental impacts can affect important ecosystem processes such as soil organic matter decomposition, plant regeneration, succession of vegetation and microbial activities. The intensity of these effects depends upon the severity and spatial variability of SWR (Jungerius and de Jong, 1989; Ritsema and Dekker, 1994) and its severity and persistence (Zavala et al., 2009b). The enhanced SWR by high RH found in this study, therefore, can result in more intensive environmental change than the generic SWR under dry conditions. In nature, high RH conditions often precede precipitation events or wetting front advances in the soil, which in turn could increase SWR (Doerr et al., 2002; Zavala et al., 2009b).

The results of the current study suggest that this will also be the case for soils in which water repellency was enhanced by soil heating during fire. Considering that the removal of the protective vegetation cover by fire increases the susceptibility of burned hillslopes to accelerated hydrological and erosional responses (Shakesby and Doerr, 2006), the enhancement of SWR at high RH may be even more influential in recently burned compared to unburned environments.

\section{Conclusions}

examined for heat-affected (burned) soils. It was found that heat-affected soils also show the enhanced SWR that has been previously reported for soils not affected by heating. This effect 
Accepted manuscript version of: Jiménez-Pinilla, P., Doerr, S.H., Ahn, S., Lozanoa, E., MataixSolera, J., Jordán, A., Zavala, L.M. \& Arcenegui, V. (2016) Effects of relative humidity on the water repellency of fire-affected soils. Catena 138, 68-76. (doi:10.1016/j.catena.2015.11.012)

was observed at $70 \% \mathrm{RH}$ and was most pronounced at $95 \% \mathrm{RH}$. The effect of $\mathrm{RH}$ was shown in all heat-treated samples, and most pronouncedly in the samples heated at high temperatures (250-300 $\left.{ }^{\circ} \mathrm{C}\right)$ that already had a substantial increase in SWR. The fact that the latter soils, as well as model soil particles treated with a hydrophobic coating, behaved in this manner suggests that physicochemical rather than microbial effects are responsible for the rapid increases in SWR induced by RH. The finding that soils in which SWR has already been enhanced by heating exhibit further increases with $\mathrm{RH}$ emphasizes the importance of considering $\mathrm{RH}$ when investigating the environmental impact of SWR in burned areas. Furthermore, a fire burns off protective vegetation and litter, and makes burned areas even more vulnerable to hydrological and erosional responses. Enhanced SWR at high RH could, therefore, be of greater significance than in unburned vegetated terrain.

This research has been supported through the HYDFIRE (CGL2010-21670-C02-01) and the POSTFIRE (CGL2013- 47862-C2-1-R) Research Projects, funded by the Spanish Ministry of Science and Innovation and the Spanish Ministry of Economy and Competitiveness, respectively. Patricia Jiménez-Pinilla and Elena Lozano acknowledge the Spanish Ministry of

394 Economy and Competitiveness and the Regional Valencian Government for their respective fellowships. Authors thank Jorge Moltó for his help with the initial field and laboratory work at University Miguel Hernández (Spain) and Grahame Walters for his invaluable laboratory support with the climate chamber at Swansea University (UK). They also are grateful to the two reviewers and editor for their valuable comments suggested that helped to enrich the manuscript. In loving memory of Juan Ramón. The authors are grateful to him and his family for their help in the study area.

401 
Accepted manuscript version of: Jiménez-Pinilla, P., Doerr, S.H., Ahn, S., Lozanoa, E., MataixSolera, J., Jordán, A., Zavala, L.M. \& Arcenegui, V. (2016) Effects of relative humidity on the water repellency of fire-affected soils. Catena 138, 68-76. (doi:10.1016/j.catena.2015.11.012)

\section{References}

419 Ahn, S., Doerr, S.H., Douglas, P., Bryant, R., Hamlett, C.A.E., McHale, G., Newton, M.I., by a single water drop impact. Earth Surf. Proc. Land. 38, 1225-1233. 
Accepted manuscript version of: Jiménez-Pinilla, P., Doerr, S.H., Ahn, S., Lozanoa, E., MataixSolera, J., Jordán, A., Zavala, L.M. \& Arcenegui, V. (2016) Effects of relative humidity on the water repellency of fire-affected soils. Catena 138, 68-76. (doi:10.1016/j.catena.2015.11.012)

Ahn, S., 2014. Physical parameters for the manifestation of soil water repellency and their effects on rainsplash erosion of model soil particles. $\mathrm{PhD}$ thesis. Swansea University. Swansea, Wales. United Kingdom.

Atanassova, A., Doerr, S.H., 2011. Changes in soil organic compound composition associated with heat-induced increases in soil water repellency. Eur. J. Soil Sci. 62, 516-532.

Arcenegui, V., Mataix-Solera, J., Guerrero, C., Zornoza, R., Mayoral, A.M., Morales, J., 2007. Factors controlling the water repellency induced by fire in calcareous Mediterranean forest soils. Eur. J. Soil Sci. 58, 1254-1259.

Arcenegui, V., Mataix-Solera, J., Guerrero, C., Zornoza, R., Mataix-Beneyto, J., Garcia-Orenes, F., 2008. Immediate effects of wildfires on water repellency and aggregate stability in Mediterranean calcareous soils. Catena. 74, 219-226.

Bachmann, J., Ellies, A., Hartge, K., 2000a. Development and application of a new sessile drop contact angle method to assess soil water repellency. J. Hydrol. 231-232, 66-75.

Bachmann, J., Horton, R., van der Ploeg, R.R., Woche, S., 2000b. Modified sessile drop method for assessing initial soil water contact angle of sandy soil. Soil Sci. Soc. Am. J. 64, 564567.

Bachmann, J., van der Ploeg, R.R., 2002. A review on recent developments in soil water retention theory: interfacial tension and temperature effects. J. Plant Nutr. Soil Sci. 165, $468-478$.

Bachmann, J., Woche, S.K., Goebel, M.O., Kirkham, M.B., Horton, R., 2003. Extended methodology for determining wetting properties of porous media. Water Resour. Res. $39,1353-1366$.

Bachmann, J., Arye, G., Deurer, M., Woche, S.K., Horton, R., Hartge, K.H., Chen, Y., 2006. Universality of a surface tension-contact-angle relation for hydrophobic soils of different texture. J. Plant Nutr. Soil Sci. 169, 745-753. 
Accepted manuscript version of: Jiménez-Pinilla, P., Doerr, S.H., Ahn, S., Lozanoa, E., MataixSolera, J., Jordán, A., Zavala, L.M. \& Arcenegui, V. (2016) Effects of relative humidity on the water repellency of fire-affected soils. Catena 138, 68-76. (doi:10.1016/j.catena.2015.11.012)

Bán, S., Wolfram, E., Rohrsetzer, S., 1987. The condition of starting of liquid imbibition in powders. Coll. Surf. 22 (2), 291-300.

Berglund, K., Persson, L., 1996. Water repellency of cultivated organic soils. Acta Agr. Scand. $46,145-152$.

Bisdom, E.B.A., Dekker, L.W., Schoutte, J.F.T., 1993. Water repellency of sieve fractions from sandy soils and relationships with organic material and soil structure. Geoderma 56, $105-118$

Bodí, M.B., Muñoz-Santa, I., Armero, C., Doerr, S.H., Mataix-Solera, J., Cerdà, A., 2013. Spatial and temporal variations of water repellency and probability of its occurrence in calcareous Mediterranean rangeland soils affected by fires. Catena 108, 14-25.

Bryant, R., Doerr, S.H., Helbig, M., 2005. Effect of oxygen deprivation on soil hydrophobicity during heating. Int. J. Wildland Fire. 14(4), 449-455.

Burch, G.J., Moore, I.D., Burns, J., 1989. Soil hydrophobic effects on infiltration and catchment runoff. Hydrol. Process. 3, 211-222.

Carrillo, M.L.K., Letey, J., Yates, S.R., 1999. Measurements of initial soil-water contact angle of water repellent soils. Soil Sci. Am. J. 63, 433-437.

Cassie, A. and Baxter, S., 1944. Wettability of porous surfaces. Trans. Faraday Soc. 44, pp. 1116.

Certini, G., 2005. Effects of fire on properties of forest soils: a review. Oecologia 143, 1-10.

Crockford, H., Topalidis, S., Richardson, P., 1991. Water repellency in a dry sclerophyll eucalypt forest - measurements and processes. Hydrol. Process. 5, pp. 405-420.

DeBano L.F., Savage S.M., Hamilton D.A., 1976. The transfer of heat and hydrophobic substances during burning. Soil Sci. Soc. Am. Proc. 40: 779-782. 
Accepted manuscript version of: Jiménez-Pinilla, P., Doerr, S.H., Ahn, S., Lozanoa, E., MataixSolera, J., Jordán, A., Zavala, L.M. \& Arcenegui, V. (2016) Effects of relative humidity on the water repellency of fire-affected soils. Catena 138, 68-76. (doi:10.1016/j.catena.2015.11.012)

DeBano, L.F., 2000. The role of fire and soil heating on water repellency in wildland environments: a review. J. Hydrol. 231-232, 195-206.

DeJonge, L.W., Jacobsen, O.H., Moldrup, P., 1999. Soil water repellency: effects of water content, temperature and particle size. Soil Sci. Am. J. 63, 437-442.

Dekker, L.W., Ritsema, C.J., Oostindie, K., Boersma, O.H., 1998. Effect of drying temperature on the severity of soil water repellency. Soil Sci. 163, 780-796.

Dekker, L.W., Ritsema, C.J., 2000. Wetting patterns and moisture variability in water repellent duck soils. J. Hydrol. 231-232, 148-164.

Díaz-Raviña, M., Prieto, A., Bååth, E., 1996. Bacterial activity in a forest soil after heating and amendments measured by the thymidine and leucine incorporation techniques. Soil Biol. Bioch. 28, 419-426.

Doerr, S.H., 1998. On standardizing the "water drop penetration time" and the "molarity of an ethanol droplet" techniques to classify soil hydrophobicity: a case study using medium textured soils. Earth Surf. Process. Land. 23, 663-668.

Doerr S.H., Shakesby R.A., Walsh R.P.D., 1998. Spatial variability of soil water repellency in fire-prone eucalyptus and pine forests, Portugal. Soil Sci. 163, 313-324.

Doerr, S.H., Thomas, A.D., 2000. The role of soil moisture content in controlling water repellency: new evidence from forest soils in Portugal. J. Hydrol. 231-232, 134-147.

Doerr, S.H., Shakesby, R.A., Walsh, R.P.D., 2000. Soil water repellency: its causes, characteristics and hydro-geomorphological significance. Earth-Sci. Rev. 51, 33-65.

Doerr, S.H., Dekker, L.W., Ritsema, C.J., Shakesby, R.A., Bryant, R., 2002. Water repellency of soils: the influence of ambient relative humidity. Soil Sci. Am. J. 40, 779-782.

Doerr, S.H., Blake, W.H., Shakesby, R.A., Stagnitti, F., Vuurens, S.H., Humphreys, G.S., Wallbrink, P., 2004. Heating effects on water repellency in Australian eucalypt forest 
Accepted manuscript version of: Jiménez-Pinilla, P., Doerr, S.H., Ahn, S., Lozanoa, E., MataixSolera, J., Jordán, A., Zavala, L.M. \& Arcenegui, V. (2016) Effects of relative humidity on the water repellency of fire-affected soils. Catena 138, 68-76. (doi:10.1016/j.catena.2015.11.012) soils and their value in estimating wildfire soil temperatures. Int. J. Wildland Fire 13, $157-163$.

Doerr, S.H., Douglas, P., Evans, R., Morley, C.P., Mullinger, N., Bryant, R., Shakesby, R.A., 2005a. Effects of heating and post-heating equilibration times on soil water repellency. Aust. J. Soil Res. 43(3), 261-267.

Doerr, S.H., Llewellyn, C.T., Douglas, P., Morley, C.P., Mainwaring, K.A., Haskins, C., Johnsey, L., Ritsema, C.J., Stagnitti, F., Allinson, G., Ferreira, A.J.D., Keizer, J.J., Ziogas, A.K., Diamantis, J., 2005b. Extraction of compounds associated with water repellency in sandy soils of different origin. Aust. J. Soil Res. 43, 225-237

Doerr, S.H., Shakesby, R.A., 2009. Soil water repellency. Principles, causes and relevance in fire-affected environments. In: Efectos de los incendios forestales sobre los suelos en España. Ed.: Cerdà, A., Mataix-Solera, J. Cátedra Divulgación de la Ciencia. Universitat de Vàlencia. p. 57-75.

Doerr, S.H., Woods, S.W., Martin, D.A., Casimiro, M., 2009. 'Natural background' soil water repellency in conifer forests of the north-western USA: its prediction and relationship to wildfire occurrence. J. Hydrol. 371, 12-21.

Feng, G.L., Letey, J., Wu, L., 2001. Water ponding depths affect temporal infiltration rates in a water repellent sand. Soil Sci. Soc. Am. J. 65, 315-320.

Franco, C.M.M., Tate M.E., Oades, J.M., 1994. The development of water-repellency in sands: studies on the physiochemical and biological mechanisms. In: Proceedings of the $2^{\text {nd }}$ National Water Repellency Workshop. Eds Carter, D.J., Howes, K.M.W. 18-30.

Franco, C.M.M., Tate, M.E., Oades, J.M., 1995. Studies on non-wetting sands1. The role of intrinsic particulate organic matter in the development of water-repellency in nonwetting sands. Aust. J. Soil Res. 33, 253-263. 
Accepted manuscript version of: Jiménez-Pinilla, P., Doerr, S.H., Ahn, S., Lozanoa, E., MataixSolera, J., Jordán, A., Zavala, L.M. \& Arcenegui, V. (2016) Effects of relative humidity on the water repellency of fire-affected soils. Catena 138, 68-76. (doi:10.1016/j.catena.2015.11.012)

518 Goebel, M., Bachmann, J., Woche, S.K., Fischer, W.R., Horton, R., 2004. Water potential and 519 aggregate size effects on contact angle and surface energy. Soil Sci. Soc. Am. J. 68, $383-393$

521

Goebel, M., Bachmann, J., Reichstein, M., Jansenns, I.A., Guggenberger, G., 2011. Soil water repellency and its implications for organic matter decomposition - is there a link to extreme climatic events? Glob. Change Biol. 17, 2640-2656.

524

González-Peñaloza, F.A., Zavala, L.M., Jordán, A., Bellinfante, N., Bárcenas-Moreno, G-, Mataix-Solera, J., Granged, A.J.P., Granja-Martins, F.M., Neto-Paixão, H.M., 2013. Water repellency as conditioned by particle size and drying in hydrophobized sand. Geoderma 209-210, 31-40.

Gordillo-Rivero, A., García-Moreno, J., Jordán, A., Zavala, L.M., Granja-Martins, F.M., 2014. Fire severity and surface rock fragments cause patchy distribution of soil water repellency and infiltration rates after burning. Hydrol. Process. 28, 5832-5843.

Granged, A.J.P., Jordán, A., Zavala. L.M., Muñoz-Rojas, M., Mataix-Solera, J., 2011a. Shortterm effects of experimental fire for a soil under eucalyptus forest (SE Australia). Geoderma 167-168, 125-134.

Granged, A.J.P., Zavala. L.M., Jordán, A., Bárcenas-Moreno, G., 2011b. Post-fire evolution of soil properties and vegetation cover in a Mediterranean heathland after experimental recolonization and chemical changes in a soil heated at different temperatures. International J. Wildland Fire 14, 385-400. Mediterranean—dynamical analysis. Int. J. Climatol. 34 (3), 849-862. 
Accepted manuscript version of: Jiménez-Pinilla, P., Doerr, S.H., Ahn, S., Lozanoa, E., MataixSolera, J., Jordán, A., Zavala, L.M. \& Arcenegui, V. (2016) Effects of relative humidity on the water repellency of fire-affected soils. Catena 138, 68-76. (doi:10.1016/j.catena.2015.11.012)

542 Heslot, F., Cazabat, A.M., Levinson, P., Fraysse, N., 1990. Experiments on wetting on the scale of nanometers: Influence of the surface energy. Phys. Rev. Lett. 65, 599-602.

Imeson, A.C., Verstraten, J.M., Van Mulligen, E.J., Sevink, J., 1992. The effects of fire and water repellency on infiltration and runoff under Mediterranean type forests. Catena 19, $345-361$.

Jex, G.W., Blealey D.H., Hubbel, D.H., Munro, L.L., 1985. High humidity-induced increase in water repellency in some sandy soils. Soil Sci. Soc. Am. J.49, 1177-1182.

Jiménez-Morillo N.T., González-Pérez J.A., Jordán A., Zavala L.M., de la Rosa J.M., JiménezGonzález M.A., González-Vila F.J., 2014. Organic matter fractions controlling soil water repellency in sandy soils from the Doñana National Park (southwestern Spain).

Jiménez-Pinilla, P., Lozano, E., Mataix-Solera, J., Arcenegui, V., Zavala, L.M., Jordán, A., 2015. Temporal changes in soil water repellency after a forest fire in a Mediterranean calcareous soil: Influence of ash and different vegetation type. Science of the Total Environment, http://dx.doi.org/10.1016/j.scitotenv.2015.09.121.

Jordán, A., Martínez-Zavala, L., Bellinfante, N., 2008. Heterogeneity in soil hydrological response from different land cover types in southern Spain. Catena 74, 137-143.

Jordán, A., Zavala, L.M., Nava, A.L., Alanís, N., 2009. Occurrence and hydrological effects of water repellency in different soil and land use types in Mexican volcanic highlands.

Jordán, A., González, F.A., Zavala, L.M., 2010. Re-establishment of soil water repellency after destruction by intense burning in a Mediterranean heatland (SW Spain). Hydrol. assessment and geomorphological consequences. Catena 108, 1-5. 
Accepted manuscript version of: Jiménez-Pinilla, P., Doerr, S.H., Ahn, S., Lozanoa, E., MataixSolera, J., Jordán, A., Zavala, L.M. \& Arcenegui, V. (2016) Effects of relative humidity on the water repellency of fire-affected soils. Catena 138, 68-76. (doi:10.1016/j.catena.2015.11.012)

Jordán, A., Gordillo-Rivero, A.J., García-Moreno, H., Zavala, L.M., Granged, A.J.P., Gil, J., Neto-Paixão, H.M., 2014. Post-fire evolution of water repellency and aggregate stability in Mediterranean calcareous soils: a 6-year study. Catena 118, 115-123.

Jungerius, P.D., de Jong, J.H., 1989. Variability of water repellence in the dunes along the Dutch coast. Catena 16, 491-497.

King, P.M., 1981. Comparison of methods for measuring severity of water repellence of sandy soils and assessment of some factors that affect its measurement. Aust. J.Soil Res. 19, $275-285$.

Krammes, J.S., DeBano, L.F., 1965. Soil wettability: a neglected factor in watershed management. Water Resour. Res. 1, 283-286.

Leelamanie, D.A.L., Karube, J., 2007. Effects of organic compounds, water content and clay on the water repellency of a model sandy soil. Soil Sci. Plant Nutr. 53, 711-719.

Leelamanie, D.A.L., Karube, J., Yoshida, A., 2008a. Relative humidity effects on contact angle and water drop penetration time of hydrophobized fine sand. Soil Sci. Plant Nutr. 54, $695-700$

Leelamanie, D.A.L., Karube, J., Yoshida, A., 2008b. Characterizing water repellency indices: contact angle and water drop penetration time of hydrophobized sand. Soil Sci. Plant Nutr. 54, 179-187.

Letey, J., Carrillo, M.L.K., Pang, X.P., 2000. Approaches to characterize the degree of water repellency. J. Hydrol. 231-232, 61-65.

Martínez-Zavala, L., Jordán-López, A., 2009. Influence of different plant species on water repellency in Mediterranean heathland soils. Catena 76, 215-223. 
Accepted manuscript version of: Jiménez-Pinilla, P., Doerr, S.H., Ahn, S., Lozanoa, E., MataixSolera, J., Jordán, A., Zavala, L.M. \& Arcenegui, V. (2016) Effects of relative humidity on the water repellency of fire-affected soils. Catena 138, 68-76. (doi:10.1016/j.catena.2015.11.012)

Mataix-Solera, J., Gómez, I., Navarro-Pedreño, J., Guerrero, C., Moral, R., 2002. Soil organic matter and aggregates affected by wildfire in a Pinus halepensis forest in a Mediterranean environment. Int. J. Wildland Fire 11, 107-114.

Mataix-Solera, J., Doerr, S.H., 2004. Hydrophobicity and aggregate stability in calcareous topsoils from fire-affected pine forests in southeastern Spain. Geoderma 118, 77-88.

Mataix-Solera, J., Arcenegui, V., Guerrero, C., Jordan, M.M., Dlapa, P., Tessler, N., Wittenberg, L.. 2008. Can terra rossa become water repellent by burning? A laboratory approach. Geoderma 147, 178-184.

Mataix-Solera, J., Guerrero, C., García-Orenes, F., Bárcenas, G.M., Torres, M.P., 2009. Forest fire effects on soil microbiology. In: Fire effects on soils and restoration strategies. Ed. Cerdá, A., Robichaud, P.R. Land Recon. Manage. 5, p. 133-175.

Mataix-Solera, J., Cerdà, A., Arcenegui, V., Jordán, A., Zavala, L.M., 2011. Fire effects on soil aggregation: a review. Earth-Sci. Rev. 109, 44-60.

Mataix-Solera, J., Arcenegui, V., Tessler, N., Zornoza, R., Wittenberg, L., Martínez, C., Caselles, P., Pérez-Bejarano, A., Malkinson, D., Jordán, M.M., 2013. Soil properties as key factor controlling water repellency in fire-affected areas: evidences from burned sites in Spain and Israel. Catena 108, 6-13.

McGhie D.A., Posner A.M., 1980. Water repellence of a heavy textured Australian surface soil. Aust. J. Soil Res. 18, 309-323.

McHale, G., Newton, M.I., Shirtcliffe, N.J., 2005. Water-repellent soil and its relationship to granularity, surface roughness and hydrophobicity: a materials science view. Eur. J. Soil Sci. $56,445-452$.

Moody, J.A., Ebel, B.A., 2012. Hyper-dry conditions provide new insights into the cause of extreme floods after wildfire. Catena 93, 58-63. 
Accepted manuscript version of: Jiménez-Pinilla, P., Doerr, S.H., Ahn, S., Lozanoa, E., MataixSolera, J., Jordán, A., Zavala, L.M. \& Arcenegui, V. (2016) Effects of relative humidity on the water repellency of fire-affected soils. Catena 138, 68-76. (doi:10.1016/j.catena.2015.11.012)

613

614

615

616

617

618

619

620

621

622

623

624

625

626

627

628

629

630

631

632

633

634

635

636

Naasz, R., Michel, J.-C., Charpentier, S., 2005. Measuring hysteric hydraulic properties of peat and pine bark using a transient method. Soil Sci. Soc. Am. J. 69, 13-22.

Neary, D.G., Klopatek, C.C., DeBano, L.F., Ffolliott, P.F., 1999. Fire effects on belowground sustainability: a review and synthesis. For. Ecol. Manag. 122, 51-71.

Ritsema, C.J., Dekker, L.W., Hendrickx, J.M.H., Hamminga, W., 1993. Preferential flow mechanism in a water repellent sandy soil. Water Resour. Res. 29, 2183-2193.

Ritsema, C.J., Dekker, L.W., 1994. How water moves in a water repellent sandy soil: 2. Dynamics of fingered flow. Water Resour. Res. 30, 2519-2531.

Roberts, F., Carbon, B., 1971. Water repellency in sandy soils of south-western Australia. 1. Some studies related to field occurrence. Field Stat. Rec. 10, pp. 13-20.

Robichaud, P.R., Hungerford, R.D., 2000. Water repellency by laboratory burning of four northern Rocky Mountain forest soils. J. Hydrol. 231-232, 207-219.

Roy, J.L., McHill, W.B., 2002. Assessing soil water repellency using the molarity of ethanol droplet (MED) test. Soil Sci. 167, 83-97.

Shakesby R.A., Doerr S.H., Wildfire as a hydrological and geomorphological agent. Earth-Sci. Rev. 74, 2006, 269-307. DOI:10D1016/j.earscirev.2005Đ10Đ006.

Shirtcliffe, N.J., McHale, G., Pyatt F.B., Newton, M.I., Doerr, S.H., 2006. Critical conditions for the wetting of soils. Appl. Phys. Lett. 89, Art. No. 094101.

Soil Survey Staff, 2014. Keys to Soil Taxonomy. $12^{\text {th }}$ edition. Washington, DC.

Wallach, R., Graber, E.R., 2007. Infiltration into effluent irrigation-induced repellent soils and the dependence of repellency on ambient relative humidity. Hydrol. Process. 21, 23462355.

Wallis, M.G., Scotter, D.R., Horne, D.J., 1991. An evaluation of the intrinsic sorptivity water repellent index on a range of New Zealand soils. Aus. J. Soil Res. 29, 353-362. 
Accepted manuscript version of: Jiménez-Pinilla, P., Doerr, S.H., Ahn, S., Lozanoa, E., MataixSolera, J., Jordán, A., Zavala, L.M. \& Arcenegui, V. (2016) Effects of relative humidity on the water repellency of fire-affected soils. Catena 138, 68-76. (doi:10.1016/j.catena.2015.11.012)

637

638

639

640

641

642

643

644

645

646

647

648

649

650

651

652

653

654

655

656

657

658

Wallis, M.G. and Horne, D.J., 1992. Soil water repellency. Adv. Soil Sci. 20, 91-146.

Wenzel, R.N., 1936. Resistance of solid surfaces to wetting by water. Ind. Eng. Chem. 28(8), pp. 988-994.

Wessel, A.T., 1988. On using the effective contact angle and the water drop penetration time for classification of water repellency in dune soils. Earth Sur. Process. Land. 13, 555-562.

Whelan, A., Kechavarzi, C., Coulon, F., Doerr, S.H., 2015. Experimental characterization of the impact of temperature and humidity on the breakdown of soil water repellency in sandy soils and composts. Hydrol. Process. 29, 2065-2073.

Widden, P., Parkinson, D., 1975. The effects of a forest fire on soil microfungi. Soil Biol. Biochem. 7, 125-138.

Zavala, L.M., González, F.A., Jordán, A., 2009a. Fire-induced soil water repellency under different vegetation types along the Atlantic dune coast-line in SW Spain. Catena 79, $153-162$.

Zavala, L.M., González, F.A., Jordán, A., 2009b. Intensity and persistence of water repellency in relation to vegetation types and soil parameters in Mediterranean SW Spain. Geoderma 152, 391-374.

Zavala, L.M., Granged, A.J.P., Jordán, A., Bárcenas-Moreno, G., 2010. Effect of burning temperature on water repellency and aggregate stability in forest soils under laboratory conditions. Geoderma 158, 366-374.

Zavala, L.M., García-Moreno, J., Gordillo-Rivero, A.J., Jordán, A., Mataix-Solera, J., 2014. Natural soil water repellency in different types of Mediterranean woodlands. Geoderma 226-227, 170-178. 